\title{
THE EFFECT OF USING DEMONSTRATION METHOD ON THE STUDENTS' ACHIEVEMENT IN WRITING PROCEDURE TEXT
}

\author{
*Yusrida \\ **Masitowarni Siregar
}

The objective of this study was to find out whether demonstration method has a significant effect on students' achievement in writing procedure texts. The population of the study was 90 third year students at SMP Negeri II Tambangan, in three classes. Sixty students were taken as the sample by using random sampling. The sample was divided in to two groups. Thirty students as the experimental group were taught by using a demonstration method and thirty students as the control group were taught by using a teacher's method. The instrument used in this study was a writing test. To obtain test reliability, the Person Product Moment Formula was used and the calculation showed that the reliability of the test was 0.95 . Then, after analyzing the data, it was found that the t-test was 3.33 with a freedom degree of 58 at the level significance $(\mathrm{p}=$ $0.05)=2.000$ meaning that $t$-test was higher than t-table $(3.33>2.000)$. Based on the result, the Ha was accepted. The result suggested that the demonstration method had a significant effect on students' achievement in writing procedure text.

Key Words: Demonstration Method, Teacher's Method, Writing, Procedure Text.

* A graduate of English Language and Literature Department of UNIMED

** A lecturer of English Language and Literature Department of UNIMED 


\section{INTRODUCTION}

\section{Background of the Study}

In learning English, learners have to be able to acquire the four language skills, namely listening, speaking, reading, and writing. It is expected that the students will be able to use English both in oral and written communication that can be useful for their further studies. But the reality shows that students' ability in the four skills, especially in writing skill, is not as satisfying as the government has expected them to be. In order to understand the language skills, especially writing skill, one should well comprehend the elements of a paragraph (Competency Based on Curriculum 2004). Writing is one of the most powerful communication tools used today and for the rest of our life. Writing is a process of transforming thoughts and ideas into written form. Writing is not only a process of linking words into sentences or paragraph, but it is a sequence or steps of ideas, organized thoughts and feeling in the form of words and combined into sentences into form of paragraphs in which every sentence is closely related one another.

Writing well is not just an option for young people - it is a necessity. Along with reading comprehension, writing skill is a predictor of academic success and a basic requirement for participation in civic life and in the global economy. There are several types of writing such as procedure, narrative, descriptive, recount, explanation, analytical exposition, hortatory exposition, report, discussion, review, news item, anecdote, spoof, but this study will focus on the procedure only.

Procedure writing is as one type of writing genre which is found in our daily life. Knapp and Watkins (2005) state that "we need to be competent in this genre". The students are expected to gain competence in understanding how English works in all categories of texts.

Since writing is the most difficult process in language proficiency, students have to study harder to be able to write effectively. According to Pennington (1995: 707), a product-oriented approach can be used to teach writing. Most students do not know how to compose texts independently. Then, writing requires good grammar. A non-native person has to remember a large number of rules in structure, which are quite different from their own language. As a result, when students write something, they have big questions in mind whether or not what they write is correct. In conclusion, writing is the 
most difficult skill that learners of any foreign language may face. To be good at it, learners must give sufficient effort.

There are some reasons why these problems emerge. Firstly, most students do not enjoy writing. They find teachers' way of teaching is boring and uninteresting. Secondly, students lack confidence in writing on their own. Many students do not have good control over their speech and language. They make a lot of errors in grammar, usage, punctuation and spelling. They may not have developed a good understanding about a variety of sentences ranging from simple to compound to complex and may not be able to use big words and appropriate synonyms. Such students tend to present an awful essay which the teachers do not like to read. Such essays receive less scoring and thus decrease their confidence. Students find it difficult to write a procedure text because they can not arrange the steps of the procedure text writing.

Demonstration method can be helpful for teachers in teaching how to write a procedure text. According to the Barton, et al. (1976: 157), the demonstration method, when properly selected and used, may be very effective. It is not a universal method; however, demonstration method is most likely to be successful (1) in teaching operative skills (2) in developing understandings, (3) in showing how to carry out new practice, and (4) in securing the acceptance of new and improved ways of doing things. After the demonstration method has been applied in the teaching learning process, students will develop more understanding of a procedure or steps in doing something. This method will improve students' ability in writing a procedure text.

\section{Research Question}

Based on the background of study, the problem was formulated as the following: "Is there any significant effect of using demonstration method on the students' achievement in writing a procedure text?".

\section{Objective of the Study}

The objective of the study was to find out if there is a significant effect of using demonstration method on the students' achievement in writing a procedure text. 


\section{Significance of the Study}

After completing this study, it is expected that the findings will be useful for:

1) Teachers of English who might consider the implementation of demonstration method to improve their teaching learning process especially in teaching a procedure text writing class.

2) Students who might use this information to enlarge their knowledge in writing a procedure text and,

3) Other researchers who are interested in using the demonstration method and conducting similar studies with different participants.

\section{Conceptual Framework}

\section{Definition of Writing}

Commonly, writing is a process done by people when they want to perform the idea in their mind into written language. In a process of writing people use the words to express the feeling, idea, or intention into written forms. On the other hand, writing is not merely a process of thinking of something to say and selecting the words needed to express it. It is kind of technique in arranging ideas or information into condensed form of writing.

Writing is a process of putting letters, symbols, numbers, or words, on paper or computer screen. It is an activity or skill of marking coherent. People can write on a paper or type on a monitor screen. As the main purpose of writing is communication, the relation of sentences in a writing should be coherent one another, so that the information that will be delivered by the writer can be understood by the reader in its publication. 
In addition, Zamel (1982: 195) defines writing as a process through which meaning is created. This leads to composition instructions that recognize the importance of generating, formulating, and refining one idea.

Elbow as quoted by Brown (2001: 336) states that in writing we do a two-step process. First, we figure out our meaning, and then we put into language. Figure out what we want to say; do not start writing until we do; make a plan; use an outline; begin writing only afterwards. Central to his model is the idea of keeping control, keeping things in hands.

It can be stated that in a process of writing, a writer should make an outline of what they want to write. It is done to make the process of writing controllable. The outline will help the writer elaborate the idea in the writing process.

In conclusion, writing is a mental process of inventing the ideas, expressing them into written forms, and organizing them into meaningful statements or paragraphs.

\section{Achievement of Writing}

According to Hornby (1995:10), the word 'achivement' means a thing done successfully, especially with effort and skill. Achievement in writing can be reached by making a good effort in the teaching and learning process. In order to improve writing achievements, both studenets and teacher should work together to perform a communiative and creative class. Good efforts such as making well-prepared lesson plan and providing appropriate media for the teaching and learning process can help students study writing effectively.

It is clear that in teaching writing, the teacher should make every effort in the classroom by providing a good lesson plan and media so that students' writing achievement can be improved.

\section{Writing Process}

Writing is a uniquely individual undertaking and the same individual may use different methods to express him or herself. Characteristically, the writing process approach recognizes that there are many stages to writing and that these stages are fluid and overlapping (Bereiter \& Scardamalia, 1983; Flower \& Hayes, 1980; Murray, 1982). Raimes (1993) cited in Nunan, 1999, p. 273) identifies two kinds of writing in the EFL 
classroom, namely "writing for learning", which includes pre-writing, drafting, revising and editing, and "writing for display" such as examination writing.

The following figure is the writing process:
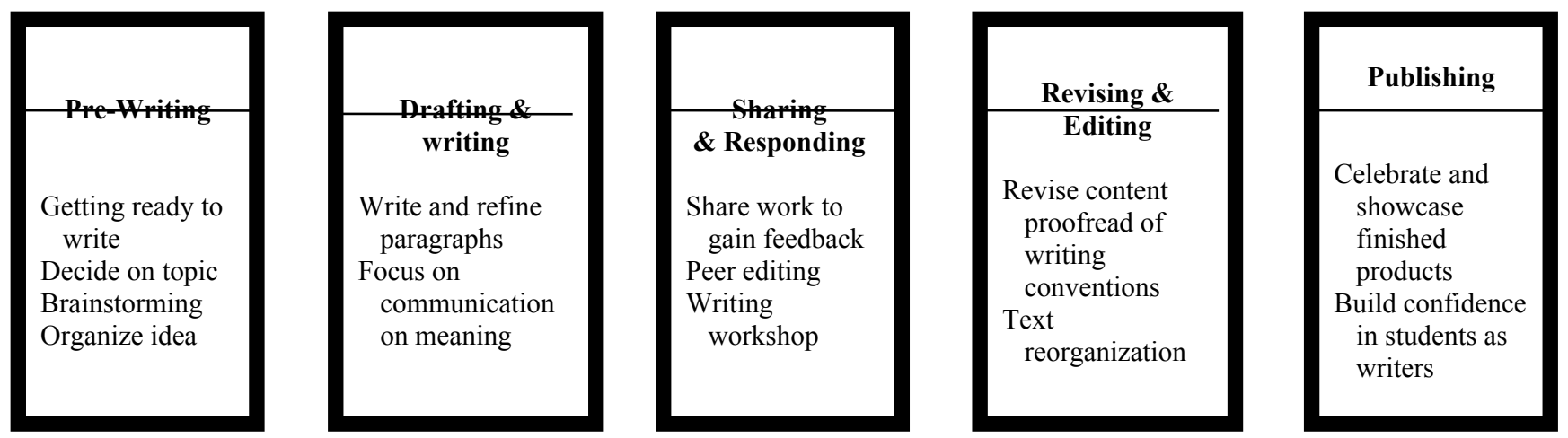

Figure 2.1 Writing Process

(Taken from: www.ksbe.edu/spi/pdfs/reports/writringProcessReport/pdf)

(Bereiter \& Scardamalia, 1983; Flower \& Hayes, 1980; Murray, 1982).

\section{Pre-writing:}

Pre-writing or plan out what is going to be written is an essential step in the writing process and should account for 70 percent of the writing time (Murray, 1982). Research indicates that skilled writers spend significantly more time organizing and planning what they are going to write (Hillocks, 1986). Most of students, however, spend on average only about 3 minutes to prepare for their writing (National Center for Educational Statistics, 1996). Students spend little time thinking and planning how to express their thoughts before writing them down and therefore are not accessing information and ideas that could possibly enhance their writing.

2. Drafting and Writing:

The phase is where students actually write and refine their ideas in a composition. Students are "encouraged to get their words and ideas on paper and 
attempt to spell whatever words they want to use" (Stice, Bertrand, \& Bertrand, 1995, p. 216). Students often write on every other line of their papers and conventions such as sentence structure, punctuation, capitalization, and spelling are not stressed during this phase. An important component to the writing process is its recursive nature, which allows writers to revise their work continually. Evidence shows that writers not only revise what they are writing, but also revisit their goals and plans for writing. This process allows writers to take into account new ideas and thoughts and to have the opportunity to incorporate it into their writing.

3. Sharing and Responding:

When the products of writing have been finished, they can be shared to the readers. The readers will read and respond them in order to help the writer improve his or her writing. In a classroom, the teacher may ask the students to write first on a paper about their idea. Later, the teacher can check the product of writing done by the students, give some respond, and revise the mistake.

4. Revising and Editing

In a writing process, some errors might be done by the writer, like the wrong dictions and ungrammatically correct sentences. Therefore, revision and edition are needed in order to improve one's writing skill. The writer can revise the content of the writing and reorganize the text. The final result of the writing will be better than the first writing. Give students an opportunity to take a second look. It is important that teachers understand the wide range of writing activity that falls within the general topic of revising. In some cases, revising might mean beginning a whole new draft, especially if writing the first draft has led the student in a new direction or given the student a new idea. In other cases, revising can mean refining the content, the organization (cut and paste), word choice, and sentence structure. It is important to teach students how to revise. They also can share their work with others and invite classmates to ask questions about the parts they want to know more about.

\section{Genres of Writing}

According to Knapp and Watkins (2005), genre is an organizing concept for cultural practices. Genres are classified according to their social purposes. There are five fundamental genre of writing: describing, instructing, arguing, explaining, and narrating. 
Gerot and Wignell (1994) state that different genres deploy the resource for meaning making through the grammar in different ways. These genres arose in social interaction to fulfill human's social purposes. There are different types of texts: spoof, recount, report, analytical exposition, news item, anecdote, narrative, procedure, description. hortatory exposition, explanation, discussion, and review.

\section{Procedure Text}

Knapp and Watkins (2005) state that procedure is an order of doing something through a sequence of action or steps. The purpose of a procedure text is to tell the reader what to do or how to do something; this can be achieved through arrangement of textual forms. Procedure may also refer to a set of commands that show how to prepare or make something. Procedures are instructions full of commands. Recipes are example of a procedure. Procedure involves a sequence of technical details. To be a procedure, a text must include at least one instruction or step that the reader should take. In brief, a procedure may also refer to away or method of doing something. So, the procedure as a genre has a series of steps followed in a regular, orderly, definitely way.

\section{Structure of Procedure Writing}

A procedural instruction such as recipes and directions are concerned with telling someone how to do something. For this reason, procedure text generally begins with the goal of the task, which is usually stated as a heading; for example "how to make sandwich" or "how to make a transplant of a tree" following this state, a set of ingredients or the materials required to complete the task will often be presented in the order of use (not require for all procedural text). Some instruction such as directions and appliance may not include this information the text then proceed through a sequence of steps specifying how the goal is to be achieved. The steps may be accompanied by illustrations or diagram to assist the reader with the task at hand. Some text may include comments at certain stages of the procedure (Knapp and Watkins: 2005)

\section{Grammatical feature of procedure}


Knapp and Watkins (2005) state that there are some grammatical features of procedure such as:

1) Action verbs:

Action verb are used in instruction to represent the process involved in the completing a task; for example: spread butter on the bread evenly and put the other loaf or bread on top.

2) Simple present tense;

Verbs are in the simple present tense to create a sense of timelessness. They are also stated as imperatives, for example: spread the better evenly and don't forget in tomato and cucumber.

3) Adverbs;

Adverbs are often used to qualify verbs and provide extra information about how a task should be complete, for example: spread butter on the bread evenly.

4) Temporal connectives:

Temporal connectives are used in procedural instructions to ensure processes are placed in the correct order of time, for example: First of all, spread butter on the bread evenly; then, put in the lettuce; finally, put the other loaf or bread on top.

5) Conditional connectives:

Conditional connectives are used to provide a premise upon which a command or statement is based, for example: If you spread the butter evenly, there won't be any lump.

\section{Teaching Method}

Method is a set of procedures or collection of technique used in a systematic way to accomplish something in learning process. Anthony as quoted in Brown (2001: 14) describes method as an overall plan for systematic presentation of language based upon a selected approach. Commonly used teaching methods may include:
a. class participation,
b. demonstration,
c. recitation
d. memorization, or combinations of these

But this study used demonstration method in teaching learning process. 


\section{Demonstration Method}

Demonstration means an act of showing something by proof or evidence. From the definition, it can be seen that the purpose is to show and to explain how something works or is accomplished. So that the audience get the message clearly since they listen, know, and see the steps of how something is done.

According to the Barton, et al. (1976: 157) the demonstration method, when properly selected and used, may be very effective. It is not a universal method, however, demonstration are most likely to be successful (1) in teaching operative skills (2) in developing understandings, (3) in show how to carry out new practice, and (4) in securing the acceptance of new and improved ways of doing things.

Demonstration method develops students' understanding or makes them easier to understand how something is done. So, students find it easy to write what they have seen, listened, and practiced.

According to Barton, et al. (1976: 157) there are seven advantages of demonstration method:

1. Demonstrations attract and hold attention; they are interesting.

2. Demonstrations present subject matter in a way that can be understood easily.

3. They convince those who might otherwise doubt that a thing could be done, or that they themselves could do it.

4. The demonstrations method is objective and concrete.

5. Demonstrations permit the teaching of theory along with practice.

6. Demonstrations yield a high rate of "take" to "exposures".

7. They aid in developing local leadership.

\section{Procedure of Writing Demonstration Method}

The followings are the procedures of applying the Demonstration method in teaching writing:

1. Planning and preparation

The teacher plans the step in the demonstrational process, including the things that should be done and the key points to be emphasized whit each step. And also prepare apparatus required for the experiment. 
2. Introducing of the lesson

The teacher explains the goal of the learning, so that the students know what they will do.

\section{Performance}

In performance, the teacher has to focus on the students whether they can view the object of what the teacher performed. Then, the teacher demonstrates each step slowly and carefully. And add demonstration with illustration and explanation.

4. Supervision

The teacher asks students to write the goal of previous performance, the material used, and all steps demonstrated by the teacher.

Writing is found to be difficult to be mastered by students. They have to study harder in order to write effectively. There are some reasons why writing is difficult for students. Firstly, writing requires good grammar in its process, while most students do not really like to study grammar. Secondly, people are often known to spend less time to write than to listen, to speak, and even to read. Thirdly, most students are not confident in writing. They usually think that their writing is bad.

In addition, the students are not able to write a procedure text because they can not arrange the steps of the writing procedure text or can not arrange the sequence of steps in good order.

By using demonstration method in teaching procedure text, it will develop understanding of students in writing the steps of sequence in good order. The students will be able to see the steps of doing or making something closely and directly. So, the students will be able to arrange the steps of writing procedure easily.

Considering the reasons above, the demonstration method gives a significant effect on students' achievement in writing a procedure text.

\section{Hypothesis}

Based on the theoretical and conceptual framework above, the hypothesis can be formulated as follow: There is a significant effect of using demonstration method on students' achievement in writing a procedure text. 


\section{METHODOLOGY}

\section{Research Design}

The research was conducted by using experimental research. To collect data, two groups were used. They are experiment and control groups. The experimental group was the group receiving the treatment of demonstration method, while the control group was the group receiving the treatment of the teacher's method. The design could be described as the following:

Table 3.1

Experimental Research Design

\begin{tabular}{|c|c|c|c|}
\hline Group & Pre-test & Treatment & Post-test \\
\hline Experimental & $\mathrm{X} 1$ & $\checkmark$ & $\mathrm{X} 2$ \\
\hline Control & $\mathrm{Y} 1$ & - & $\mathrm{Y} 2$ \\
\hline
\end{tabular}

Where: $\mathrm{X} 1=$ Pre- test of experimental group

Y1 $=$ Pre-test of control group

$\mathrm{X} 2=$ Post-test experimental group

Y2 $=$ Post-test control group

$\checkmark=$ Teaching writing by using demonstration method

- = Teaching writing without demonstration method

\section{Population and Sample}

The population of this research was taken from the third year students at SMPN II Tambangan which consists of three classes and a total number of 90 students. And the sample of this study was taken by random sampling using a lottery technique. Two classes were chosen as the sample of this study.

The experimental group was taught how to write procedure text by using the demonstration method while the control group was taught by using the teacher's conventional teaching method.

\section{Validity and Reliability}

A test is said to be good if it is valid and reliable. To ensure that the test is already good both its validity and reliability should be established. 
According to Harrison (1983: 140) the validity of the test means the test measures what is intended to measure; whether it is achievement of the skill of language or attitude towards a language. There are three types of validity, namely: content validity, criterion related validity and construct validity. This study used content validity. It is concerned with how well the test measures the subject matter and learning outcomes covered during the instruction period. The content validity of the test may show that a test represents all materials objectives to be obtained by students.

Reliability is a necessary characteristic of any good test: for it to be valid at all, a test must fist be reliable as a measuring instrument. If the test is administrated to the same candidates on different occasions and produces differing results, it might be unreliable.

Vockel (1983: 37) says that in inter-rater reliability, coefficient correlation between the two sets of scores can be computed if two different persons have the test. The coefficient correlation can be obtained by using the person product moment formula as follows:

$$
r=\frac{N\left(\sum x y\right)-\left(\sum x\right)\left(\sum y\right)}{\sqrt{\left[\left(N \sum x^{2}-\left(\sum x\right)^{2}\right)\left(N \sum y^{2}-\left(\sum y\right)^{2}\right]\right.}}
$$

Where: $r=$ the reliability

$$
\begin{aligned}
& \sum \mathrm{y}=\text { sum of scorer } \mathrm{Y} \\
& \sum \mathrm{x}=\text { sum of scorer } \mathrm{X} \\
& \mathrm{N}=\text { the number of students }
\end{aligned}
$$

According to Aruan (2002), the reliability of the test can be categorized as follows:

1. $0,00-0,20=$ very low reliability

2. $0,21-0,40=$ low reliability

3. $0,41-0,60=$ fair reliability

4. $0,61-0,80=$ high reliability

5. $0,81-1,00=$ very high reliability

\section{Research Procedure}

To obtain the data of this study, three procedures were taken by the writer namely: pre-test, treatment, and post-test. 


\section{Pre-Test}

Before the treatment, a pre-test was administrated to the experimental group and control group. The pre-test was used to find the mean scores of each group.

\section{Treatment}

The treatment was conducted after the administration of the pre-test. The experimental group was taught by using the demonstration method while the control group was taught by using the teacher's method.

\section{Experimental Group}

The treatment was conducted after the administration of pre-test. The experimental group was taught in six meetings. The teacher gave the presentation to the experimental group by the following procedures:

Table 3.4

Teaching Procedure of Experimental Group

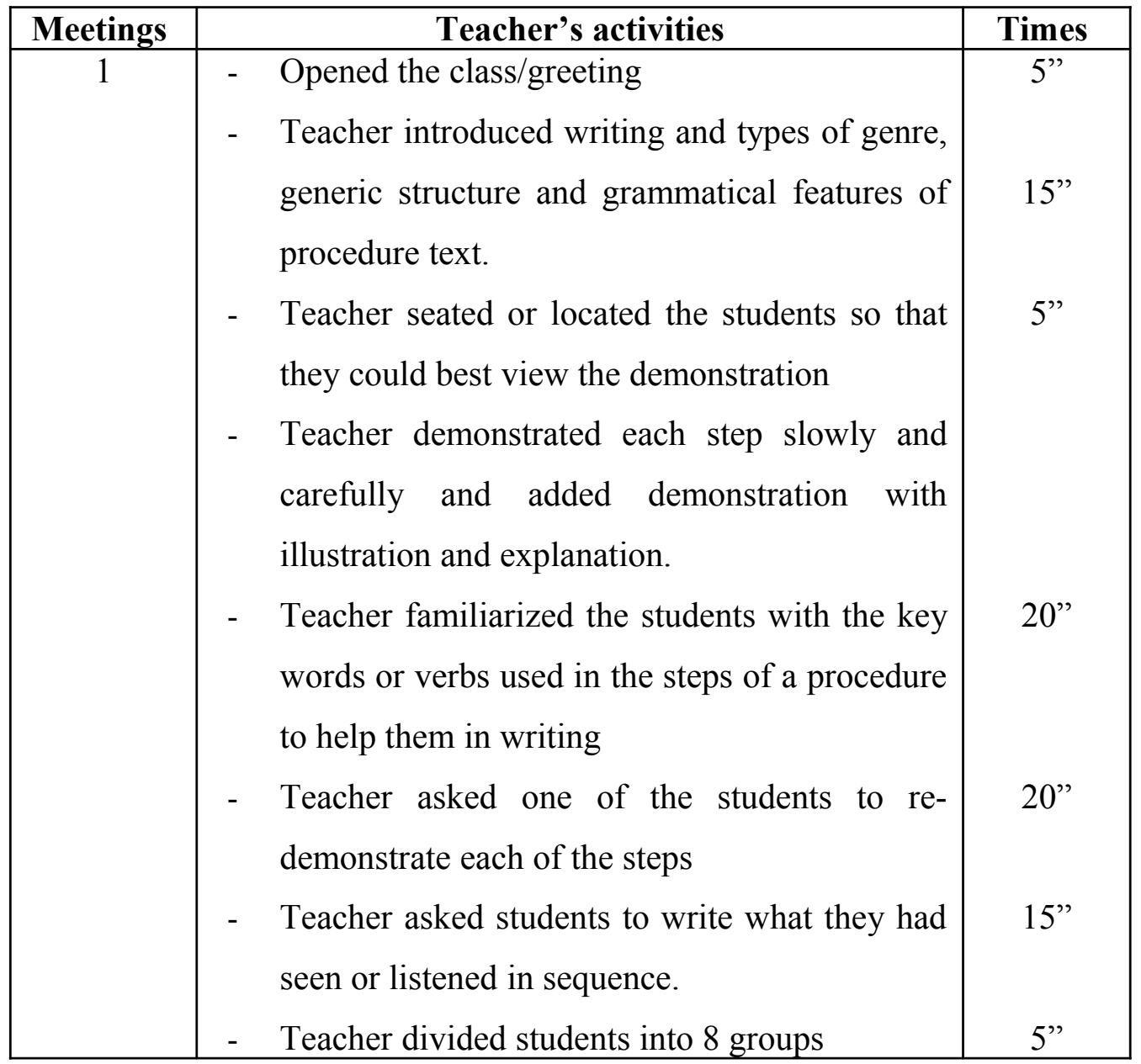




\begin{tabular}{|c|c|c|c|}
\hline & & $\begin{array}{l}\text { Ended the class by asking each group to } \\
\text { prepare the materials needed for the next } \\
\text { meeting. }\end{array}$ & $5 "$ \\
\hline 2 & - & $\begin{array}{l}\text { Opened the class/greeting } \\
\text { Teacher formed the class, so all students could } \\
\text { view the demonstration. } \\
\text { Teacher asked each group to put the material } \\
\text { on the table. } \\
\text { Teacher demonstrated each step slowly and } \\
\text { carefully, added demonstration with illustration } \\
\text { and explanation and asked each group to } \\
\text { follow the steps in their seat. } \\
\text { Teacher asked some of the groups to re- } \\
\text { demonstrate each of the steps. } \\
\text { Ended the class by asking each group to find a } \\
\text { new goal and prepare the materials needed }\end{array}$ & $50 ”$ \\
\hline 3 & - & $\begin{array}{l}\text { Opened the class/greeting } \\
\text { Teacher asked the students to show their } \\
\text { preparation } \\
\text { Teacher asked group } 1,2,3,4 \text {, to demonstrate } \\
\text { the steps to achieve the goal } \\
\text { Teacher asked the other groups to ask what } \\
\text { they didn't understand } \\
\text { Ended the class }\end{array}$ & $\begin{array}{c}" \\
10 "\end{array}$ \\
\hline 4 & & $\begin{array}{l}\text { Opened the class } \\
\text { Teacher asked the other groups to demonstrate } \\
\text { the steps to achieve their goal } \\
\text { Teacher asked the other groups to ask what } \\
\text { they didn't understand and discussed it } \\
\text { together } \\
\text { Ended the class by asking each to find another } \\
\text { goal and prepare the tools needed }\end{array}$ & $\begin{array}{c}5 " \\
60 "\end{array}$ \\
\hline 5 & - & Opened the class & $5 "$ \\
\hline
\end{tabular}




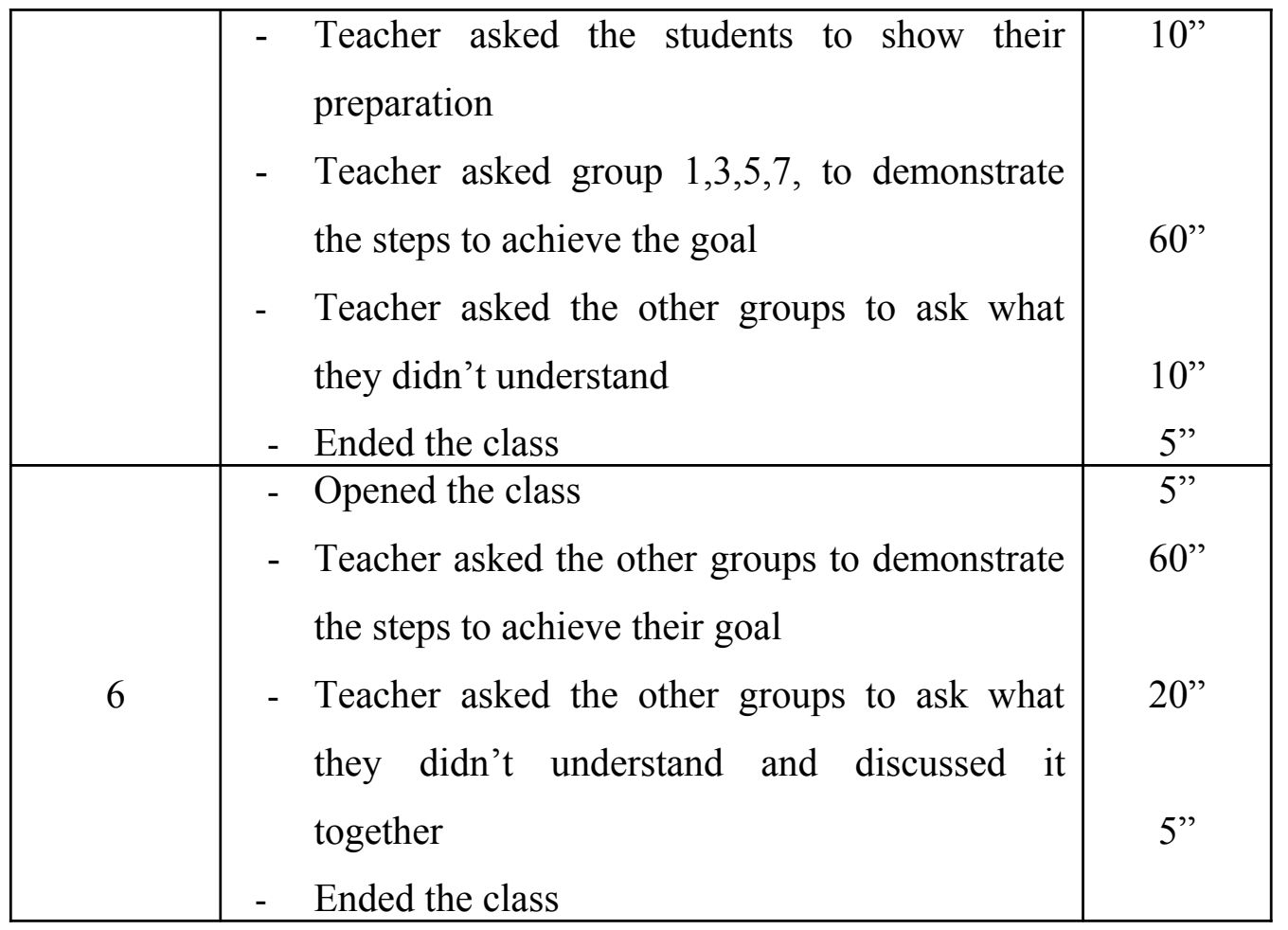

Control group

In the control group, the students were taught by using the teacher's method. In this method, students were asked to open their English book in getting some information about a procedure text.

Table 3.5

Teaching Procedure of Control Group

\begin{tabular}{|c|c|c|}
\hline Meetings & Teacher's activities & Times \\
\hline \multirow{7}{*}{1} & - $\quad$ Opened the class/greeting & $5 "$ \\
\hline & - Teacher asked the students to read their & $30 ”$ \\
\hline & English book & \\
\hline & - Teacher asked the students to write the & \\
\hline & summary of the book and write a procedure & $50 ”$ \\
\hline & text & $5 ”$ \\
\hline & - $\quad$ Ended the class & \\
\hline \multirow[t]{3}{*}{2} & - Opened the class/greeting & $5 "$ \\
\hline & - The teacher introduced writing and types of & $30 "$ \\
\hline & genre, generic structure and grammatical & \\
\hline
\end{tabular}




\begin{tabular}{|c|c|c|}
\hline & $\begin{array}{l}\text { features of procedure text. } \\
\text { - } \quad \text { Teacher distributed a text about the procedure } \\
\text { text and discussed the text. } \\
\text { - Ended the class by asking students to find out } \\
\text { other examples of procedure text at home. }\end{array}$ & $50 "$ \\
\hline 3 & $\begin{array}{l}\text { - Opened the class/greeting } \\
\text { - Teacher asked students to show their text and } \\
\text { read the text. } \\
\text { - Teacher gave the chance to students to ask } \\
\text { what they didn't understand about their text } \\
\text { and discussed it together } \\
\text { - Ended the class by dividing students into some } \\
\text { groups and asking each group to find new } \\
\text { procedure texts }\end{array}$ & $\begin{array}{c}5 " \\
15^{\prime \prime}\end{array}$ \\
\hline 4 & $\begin{array}{l}\text { - } \text { Opened the class/greeting } \\
\text { - } \text { Teacher asked students to sit with their groups } \\
\text { - } \text { Teacher asked students to discuss about their } \\
\text { text } \\
\text { - } \text { Teacher asked some groups to present the } \\
\text { results of their discussion } \\
\text { - Ended the class }\end{array}$ & $\begin{array}{l}20 " \\
60 "\end{array}$ \\
\hline 5 & $\begin{array}{l}\text { - } \text { Opened the class } \\
\text { - Teacher asked other groups to continue the } \\
\text { presentation } \\
\text { - Teacher asked the students to ask what they } \\
\text { didn't understand and discussed it together } \\
\text { - Ended the class }\end{array}$ & $\begin{array}{c}5^{\prime \prime} \\
60 "\end{array}$ \\
\hline 6 & $\begin{array}{l}\text { - } \text { Opened the class } \\
\text { - Teacher asked some students to read a } \\
\text { procedure text in front of class and discussed } \\
\text { the procedure text together } \\
\text { - Ended the class }\end{array}$ & $\begin{array}{l}5 " \\
20 " \\
60 " \\
5 "\end{array}$ \\
\hline
\end{tabular}




\section{Post-Test}

After treatment, post-test was given to each group. This post-test was exactly the same as the pre-test given to find out the mean score of experimental group and control groups.

\section{Technique of Data Analysis}

From the data, a calculation was made to find out whether or not the demonstration method was helpful in teaching a writing procedure text. The calculation was conducted by using the $\mathrm{T}_{\text {test }}$ as the following:

$$
T=\frac{M x-M y}{\sqrt{\left[\frac{d x^{2}+d y^{2}}{N x+N y-2}\right]\left[\frac{1}{N x}+\frac{1}{N y}\right]}}
$$

Where:

$$
\begin{array}{ll}
\mathrm{T} & =\text { Total score } \\
\mathrm{Mx} & =\text { Mean of experimental group } \\
\mathrm{My} & =\text { Mean of control group } \\
\mathrm{dx} & =\text { Deviation score of experimental group } \\
\mathrm{dy} & =\text { Deviation score of control group } \\
\mathrm{Nx} & =\text { Number of experimental group } \\
\mathrm{Ny} & =\text { Number of control group }
\end{array}
$$

\section{Data and Data Analysis}

Sixty students were taken as the sample of this study. They were divided into two group namely experimental group and control group. To obtain the data, a written test was given to the students. The data of this study were collected after pre-test and post-test were given applied in experimental and control group. The data were the students' scores needed for hypothesis testing.

\section{Testing the Reliability of the Test}

The reliability of the test was intended to find out whether or not the test is reliable. Inter-rate reliability was used to calculate the reliability of the test. Reliability of the test can be categorized as following:

1. $0,00-0,20=$ very low reliability 
2. $0,21-0,40=$ low reliability

3. $0,41-0,60=$ fair reliability

4. $0,61-0,80=$ high reliability

5. $0,81-1,00=$ very high reliability

From the calculation, it was found out that the reliability of the test was 0.95 indicating very high reliability.

\section{RESULTS AND DISCUSSION}

In this research, it was found out that the use of demonstration method on teaching procedure texts had a significant effect on the students' achievement in writing procedure texts. The students which were taught by using the demonstration method obtained higher score than those taught by using the teacher's method. The results of the t-test showed that, the t-test was higher than the t-table $(3.33>2.000)$. It means that there is a significant effect of using the demonstration method on the students' achievement in writing a procedure text.

\section{CONCLUSION AND SUGGESTIONS}

\section{Conclusion}

The result of t-test calculation showed that the t-test value 3.33 with a degree of freedom $(\mathrm{df})=58$ was higher than that of the t-table 2.000 at the level significance $(\mathrm{p}=$ 0.05) implying that the alternative hypothesis was accepted. It can be concluded that there is a significant effect of using the demonstration method on the students' achievement in writing a procedure text.

\section{Suggestions}

Based on the results of the study, suggestions can be made as the following:

1.

It is suggested that English teachers apply the demonstration method in teaching a procedure text as it is an interesting method and can improve students' achievement in writing a procedure text.

2. It is suggested that English teachers guide their students in writing a procedure text so that they can practice writing a procedure text more easily. 


\section{REFERENCES}

Aruan, D.M. 2007. Penafsiran Skor Test [Bachelor's thesis]. Medan: State University of Medan.

Brown, H. D. 2001. Teaching by Principles. An Interactive Approach to Language Pedagogy (2nd Ed.). New York: Pearson Education Company.

Gerrot, L., \& Wignell, P. 1994. Making Sense on Functional Grammar. Sydney: Gerd Stabler.

Harrison, B. 1983. Research. London: Heinemann International.

Hillocks, G. 1986. Research on Written Composition. Urbana: ERIC Clearinghouse.

Hornby, A.S. 1995. Oxford Advanced Learner's Dictionary of Current English. Walton Street: Oxford University Press.

Morgan, Barton, et al. 1976. Method in Adult Education (3rd Ed). Danville: The Interstate Printers \& Publisher, Inc.

Murray, D.H. 1982. Learning by teaching. NJ: Boynton/Cook.

Knapp, P., \& Watkins, M. 2005. Genre, Text, Grammar. Sydney: University of New South Wales.

Vockel, E. L. 1983. Educational Research. New York: Macmillan Publishing Co, Inc.

Writing is the Most Difficult Skill. (Anonymous, n.d.). http://language123.blogspot.com/2008/04/writing-is-most-difficult-skills.html.

Retrieved May 12, 2011.

Writing Process Report. (Anonymous, n.d.). www.ksbe.edu/spi/pdfs/reports/writingProcessReport/pdf. Retrieved May 20, 2011. 